\title{
KIMBERLITE REDEFINED
}

C.R.Clement (De Beers Consolidated Mines Limited, Box 616,

E.M.W. Skinner 8300 Kimberley, South Africa)

B.H. Scott (Anglo American Research Laboratories, Box 106, 2025 Crown Mines,
South Africa)

The term kimberlite was first proposed by Lewis (1887) when describing the "matrix of diamond" at its type locality - Kimberley, South Africa.

A number of authors have subsequently attempted to define kimberlite but we consider that none of these definitions has proved completely satisfactory, mainly because it is difficult to encompass in a single simple definition, the variety of rock types which are generally accepted as being kimberlites. Furthermore, although the mineralogical variability of kimberlite is widely recognized, most definitions fail to take into account the range of essential minerals that may be present in kimberlite. Other problems in defining kim= berlite arise out of the presence of cryptogenic minerals (often but not always interpreted as xenocrysts), the frequent presence of abundant contam= inatory xenolithic material, the presence of variable textures reflecting different near-surface emplacement processes and commonly extensive altera= tion. Some previous definitions have incorporated genetic implications (with regard to the origin of kimberlite or the minerals therein) which should not be included in a factual statement.

We therefore propose an alternative and, hopefully, more workable definition. In terms of general format this definition broadly follows that proposed by Dawson (1971) but differs in a number of important respects. We would wel= come comments which may assist in improving this proposed definition before it is submitted for publication in a form which will incorporate details of its derivation:-

KIMBERLITE is a volatile-rich, potassic, ultrabasic, igneous rock which has a distinctively inequigranular texture resulting from the presence of macro= crysts set in an essentially microporphyritic matrix.

The matrix contains as prominent primary phenocrystal and/or groundmass con= stituents, olivine and several of the following minerals: phlogopite, calcite, serpentine, diopside, monticellite, apatite, spinels, perovskite and ilmenite. other primary minerals may be present in accessory amounts.

The macrocrysts belong almost exclusively to a suite of anhedral, cryptogenic, ferromagnesian minerals which include olivine, phlogopite, picroilmenite, magnesian garnet, chromian diopside and enstatite. 0livine is extremely abundant relative to the other minerals which need not all be present. In addition to macrocrysts smaller grains belonging to the same suite also occur.

Kimberlite may contain diamond but only as a very rare constituent.

Kimberlite commonly contains rounded inclusions of a variety of ultramafic 
60

rocks characterized by mantle-derived peridotites, eclogite and pyroxenites. Variable quantities of crustal xenolith and xenocryst may also be present.

Kimberlite is often altered mainly as a result of serpentinization and/or carbonatization.

EXPLANATORY NOTES:

Volatile-rich : $\mathrm{High} \mathrm{CO}_{2}$ and $\mathrm{H}_{2} \mathrm{O}^{+}$contents relative to most other igneous rocks including other ultrabasic types.

Potassic : Refers to the high $\mathrm{K} / \mathrm{Na}$ ratios of kimberlite and high $\mathrm{K}$ relative to most other ultrabasic rocks.

Cryptogenic : Implies an unknown or hidden origin.

Macrocryst : Crystals visible to the unaided eye and significantly larger than the surrounding matrix. The term megacryst could be reserved for even larger crystals which occur in kimberlite and are commonly termed dis= crete nodules.

Picroilmenite : Ilmenites with high Mg contents.

REFERENCES :

Lewis H.C. (1887), Geol. Mag., 3 iv: 22-24

Dawson J.B. (1971), Earth Sci. Rev., 7: 187-214

Inches calcic sol tree bass ar dante normative. - def Talus. 